\title{
Platform Online Dalam Perkuliahan Pada Masa Pandemi Covid-19
}

\author{
Dewi Surani ${ }^{1}$, Jaka Wijaya Kusuma ${ }^{2}$, Nugrahini Kusumawati ${ }^{3}$ \\ ${ }^{1}$ Pendidikan Teknologi Informasi-Universitas Bina Bangsa \\ ${ }^{2}$ Pendidikan Matematika-Universitas Bina Bangsa \\ ${ }^{3}$ Akuntansi-Universitas Bina Bangsa
}

\section{INFO ARTIKEL}

\section{Riwayat Artikel:}

Diterima: 14-08-2020

Disetujui: 24-09-2020

\section{Kata kunci:}

online platform;

lectures;

the Covid-19 pandemic;

platform online;

perkuliahan;

pandemi Covid-19

\author{
Alamat Korespondensi: \\ Dewi Surani \\ Pendidikan Teknologi Informasi \\ Universitas Bina Bangsa \\ Jl. Raya Serang Jakarta KM. 1 No. 3 Pakupatan Serang \\ E-mail: suranidewiahead@gmail.com
}

Fenomena pandemi Covid-19 mengakibatkan beberapa kegiatan sehari-hari terganggu salah satunya kegiatan pendidikan. Pemerintah melalui Kementerian Pendidikan dan Kebudayaan dan Kementerian Agama RepublikIndonesia, telah menerapkan kebijakan belajar dan bekerja dari rumah sejak saat itu pertengahan Maret 2020. Sejalan dengan perkembangan informasi dan komunikasi teknologi (ICT), Covid-19 telah memaksa kampus untuk berinovasi dan bertransformasi pembelajaran, salah satunya dengan pembelajaran jarak jauh (Pujilestari 2020). Salah satu bentuk alternatif pembelajaran yang dapat dilaksanakan selama

\begin{abstract}
During the Covid-19 pandemic, lecturers and students were forced to adapt to the online lecture process by utilizing various online platforms. The purpose of this study is to explore the use of online platforms in online lectures during the Covid 19 pandemic, its strengths and weaknesses, constraints and solutions. The data were collected using a survey method by giving a questionnaire to 64 lecturer participants from all over Indonesia who were randomly selected. The results showed that lecturers were more likely to use familiar, familiar and easy-to-use platforms such as WhatsApp, followed by other platforms such as Zoom, Google Classroom while still carrying out technical implementation such as face-to-face learning such as lecture schedules on schedule, attendance attendance, fixed material referring to the RPS, evaluation of material with varied assignments and still seeking solutions to existing problems or constraints. The advantages of using online platforms include supporting the delivery of material in an attractive manner, smooth interaction, while the disadvantages are less interactive, less fluent lecture communication and tends to be one-way, wasteful of quotas, inadequate internet access, less than optimal understanding of material, and level of participation. low student. The use of online platforms in lectures during the Covid-19 pandemic requires both infrastructure and non-structural readiness to optimize the online lecture process during the Covid-19 pandemic.

Abstrak: Pada masa pandemi Covid-19 dosen dan mahasiswa dipaksa untuk beradaptasi dengan proses perkuliahan online dengan memanfaatkan berbagai platform online. pada masa pandemi covid 19, kelebihan dan kekurangnya, kendala serta solusinya. Data diambil dengan metode survei dengan memberikan angket kuesioner kepada 64 enjukan bahwa dosen lebih cenderung menggunakan paltform yang sudah familia Googl dan mudah digunakan seperti WhatsApp, diikuti platform lainnya, seperti Zoom pembelajaran tatap muka seperti jadwal pelaksanan perkuliahan sesuai jadwal, adanya absensi kehadiran, materi tetap mengacu ke RPS, evaluasi materi dengan penugasan yang variatif dan tetap mengupayakan solusi terhadap masalah atau kendala yang ada. Kelebihan pemanfaatan platform online, yaitu mendukung penyampaian materi dengan menarik, interaksi yang lancar, sementara kekurangannya ialah kurang interaktif, komunikasi perkuliahan kurang lancar dan cenderung satu arah, boros kuota, akses internet yang kurang memadai, pemahaman materi yang kurang maksimal, dan tingkat partisipasi mahasiswa yang rendah. Pemanfaatan platform online dalam perkuliahan $\mathrm{d}$ masa pandemi Covid-19 membutuhkan kesiapan baik infrastruktur maupun nonstruktur guna mengoptimalkan proses perkuliahan online selama pandemi Covid-19.
\end{abstract}


keadaan darurat Covid-19 adalah pembelajaran online (Firman \& Rahman 2020). Pembelajaran online adalah pembelajaran yang menggunakan jaringan internet dengan aksesibilitas, konektivitas, fleksibilitas, dan kemampuan menghadirkan berbagai jenis pembelajaran interaksi (Moore 2011).

Perubahan pelaksanaan pembelajaran tatap muka (offline) menjadi pembelajaran daring (online) merupakan tantangan sendiri bagi perguruan tinggi. Pembelajaran online merupakan salah satu solusi yang dibutuhkan oleh tenaga pendidik dan mahasiswa di masa pandemi ini. Dalam pelaksanaan pembelajaran online, tenaga pendidik dapat memanfaatkan kemajuan teknologi ini sebagai media pembelajaran atau perantara dalam menyampaikan ilmu pengetahuan kepada peserta didik melalui beberapa aplikasi online, seperti zoom, spada, google classroom, google meeting atau whatsapp group. Dengan menggunakan media pembelajaran tersebut, tenaga pendidik dapat membuat penjelasan materi yang menarik dan tidak monoton agar peserta didik tertarik dan tetap semangat dalam mengikuti kegiatan belajar mengajar terssebut (Surani \& Chaerudin 2019a). Implementasi pembelajaran online tidak terbatas pada situasi krisis seperti pandemi saat ini, pembelajaran online telah disarankan sebagai pengganti pembelajaran tatap muka kedepannya. Berubah metode pembelajaran dari metode konvensional menjadi metode online tentunya bukan hal yang mudah dan pekerjaan sederhana (Herliandry, dkk, 2020).

Pembelajaran online di masa pandemi dikeluhkan oleh banyak peserta didik karena dianggap kurang efektif. Dalam pembelajaran online dinilai banyak permasalahan seperti ketidaksiapan peserta didik dituntut belajar mandiri, terkendala oleh jaringan internet, kurangnya fasilitas teknologi hingga tidak stabilnya sinyal. Permasalahan tersebut menjadi tantangan bagi para tenaga pendidik, mereka harus mampu memberikan motivasi kepada peserta didik dalam melakukan pembelajaran online ini. Seorang tenaga pendidik harus mampu menginovasi dirinya dan peserta didik, maksudnya tenaga pendidik disini harus mampu membangkitkan semangat motivasi peserta didik dengan penjelasan materi dan tugas yang berbeda dengan berbagai metode belajar yang menarik (Surani \& Chaerudin 2019b). Penyesuaian diri dan pemanfaatan teknologi terkait pembelajaran daring selayaknya dilakukan oleh tenaga pendidik dan peserta didik (Susilawati and Supriyatno 2020) Selain itu, tenaga pendidik dalam pembelajaran online harus tetap memberikan penjelasan materi kepada peserta didik dan tidak hanya memberikan tugas saja, karena banyak yang terjadi bahwa dalam pembelajaran online pendidik hanya memberikan tugas saja tanpa menjelaskan terlebih dahulu. Hal itulah yang membuat semangat belajar peserta didik menurun karena mereka merasa terbebani oleh tugas yang menumpuk.

Berbagai platform online dapat digunakan untuk mendukung pelaksanaan pembelajaran secara online, misalnya kelaskelas virtual menggunakan layanan Google Classroom, Edmodo, dan Schoology (Enriquez 2014). Hasil penelitian menunjukkan bahwa platform pembelajaran daring yang menjadi preferensi mahasiswa UGM berdasarkan kriteria-kriteria persepsi responden tersebut memunculkan alternatif platform pembelajaran daring yang paling diminati oleh mahasiswa UGM adalah elisa dengan perolehan bobot akhir sebesar 0,27 diikuti oleh platform elok, classroom, zoom, meets, dan terakhir webex (Mukharomah, Mada, \& Qomariyah 2020).

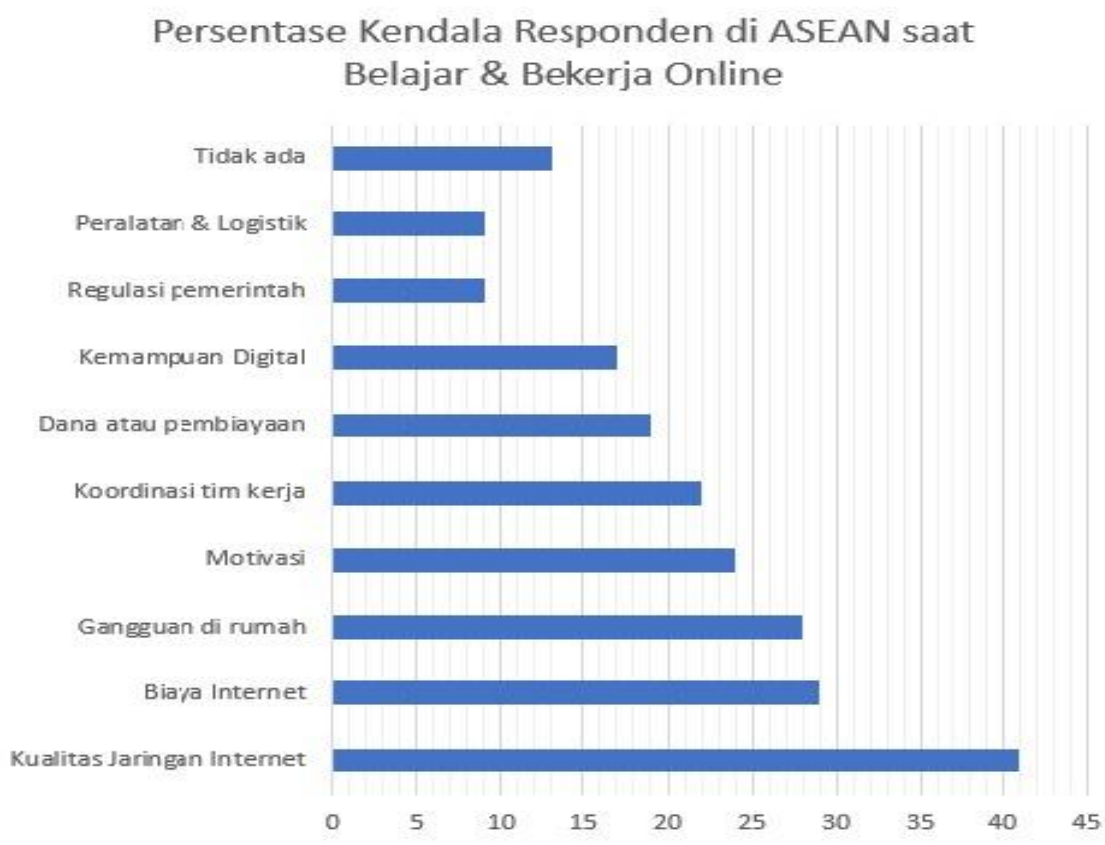

Gambar 1. Persentase kendala responden saat belanja dan belajar online 
Hasil survei Forum Ekonomi Dunia (WEF) terlihat pada gambar 1 menyebutkan anak muda di ASEAN mengalami sejumlah kesulitan dalam belajar dan bekerja secara online. Kesulitan yang paling banyak diungkapkan responden adalah kualitas jaringan internet yang buruk (41\%). Mereka juga mengatakan kesulitan lainnya, seperti biaya internet yang tinggi (29\%), gangguan di rumah (28\%), tidak adanya motivasi (24\%), dan sulitnya berkoordinasi dengan tim kerja $(22 \%)$.

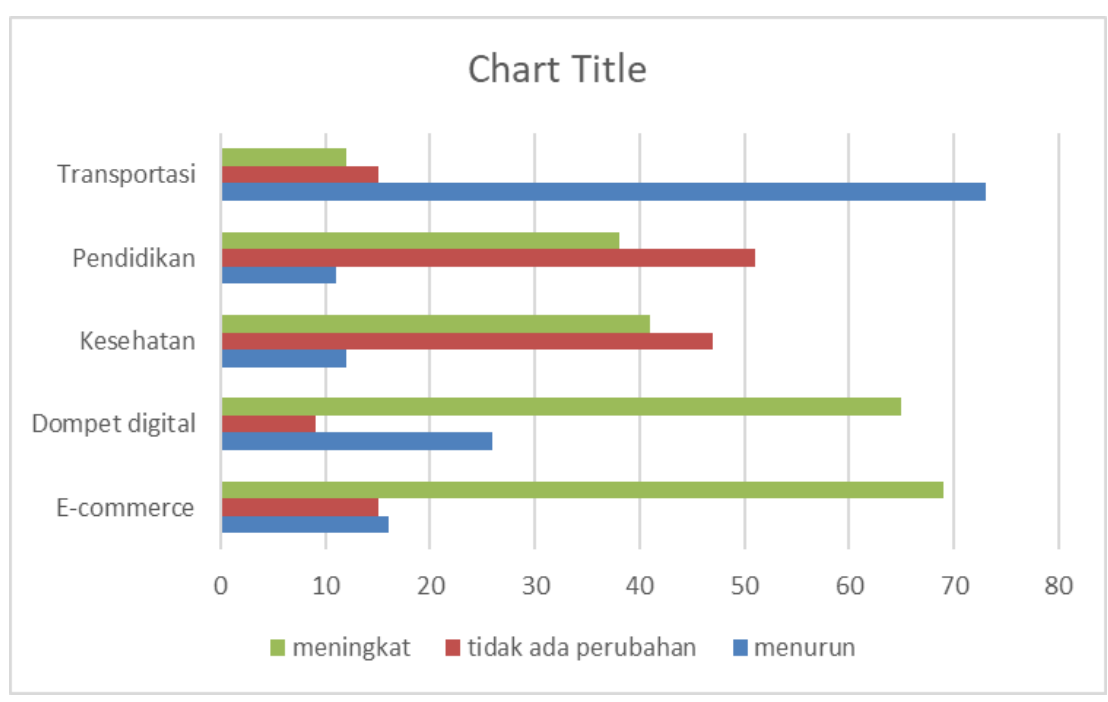

Gambar 2. Layanan digital di masa pandemi

Terlihat pada gambar 2, layanan digital dimasa pandemi mengalami kenaikan terutama di bidang kesehatan dan pendidikan yang meningkatkan masing masing sebesar $41 \%$ dan $38 \%$. Sebagian besar pelayanan kesehatan diakses untuk berkonsultasi terkait virus dan layanan pendidikan untuk pendampingan kegiatan belajar dari rumah. Penelitian ini bertujuan untuk mengeksplorasi pemanfaatan platform online oleh dosen pada perkuliahan online di masa pandemi Covid 19, kelebihan dan kekurangnya, kendala serta solusinya dalam penerapan pembelajaran online sebagai akibat dari masa pandemi Covid-19.

\section{METODE}

Penelitian ini dilakukan dengan menggunakan metode pengumpulan datanya yaitu metode survei yaitu pengumpulan data dengan memberikan angket kuesioner kepada partisipan. Partisipan dalam penelitian ini ialah dosen di seluruh wilayah Indonesia yang dipilih secara acak. Partisipan terdiri dari $82,8 \%$ dosen berada di pulau Jawa, 7,8\% berasal dari pulau Sulawesi dan selebihnya tersebar di beberapa pulau yaitu Sumatera, Kalimantan, Papua dan Bali dengan jumlah responden 64 dosen. Berikut tahapan yang dilakukan dalam penelitian ini ditunjukkan pada gambar 3.

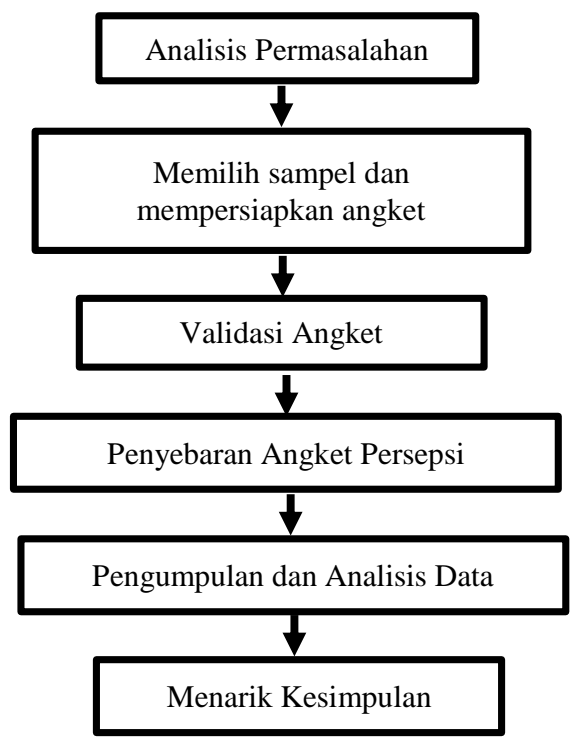

Gambar 3. Tahapan Penelitian 
Melihat diagram alir yang berisikan tahapan penelitian yang terlihat pada gambar 4, berikut kami uraikan tahapan penelitian yang dilakukan pada bulan Juni tahun 2020. Adapun uraiannya sebagai berikut.

Pertama, analisis pemanfaatan platform online dalam kegiatan perkuliahan online oleh dosen dimasa pandemic covid19. Analisa dilakukan untuk mengetahui permasalahan khususnya selama pemberlakuan pembelajaran online yang diterapkan dosen di perkuliahan.

Kedua, sampel yaitu dosen semua jurusan yang memberikan respon terhadap angket yang disebarkan secara online melalui Whatsapp Group. Selanjutnya mempersiapkan angket kuesioner sesuai permasalahan yaitu tentang pemanfaatan platform online dalam kegiatan perkuliahan online oleh dosen dimasa pandemic covid-19.

Ketiga, penyebaran angket dilakukan kepada dosen semua jurusan secara online dengan menyebarkan link googleform secara online dengan teknis oneshot by respondent yang berarti responden hanya dapat menjawab satu kali dan tidak bisa memperbaiki isian yang telah terkirim. Penyebaran kuesioner dimulai tanggal 8-14 Juni 2020. Data hasil penyebaran angket dikumpulkan baik data kuantitatif dan kualitatifnya. Dari penyebaran angket kepada seluruh dosen yang memberikan respons ada 64 dosen yang selanjutnya merupakan subjek penelitian.

Keempat, data tersebut kemudian dianalisis berdasarkan tiap pernyataan angket yang diberikan. Data kuantitatif dianalisis dengan statistik deskriptif untuk menentukan persentase dari setiap butir kuesioner. Data kualitatif dari pertanyaanpertanyaan terbuka dianalisis dengan cara analisis isi untuk memperoleh wawasan pemanfaatan platform online dalam kegiatan perkuliahan online oleh dosen di masa pandemi covid-19 untuk mendukung data kuantitatif. Kelima, penarikan kesimpulan dilakukan setelah data selesai dianalisis.

\section{HASIL}

Pandemi Covid-19 mengakibatkan bergesernya pelaksanaan pembelajaran, dari pembelajaran di kelas menjadi pembelajaran online. Hal ini hampir merata terjadi di wilayah Indonesia. Hal ini ditujukkan dengan hasil penyebaran survei online sebagai berikut.

\section{Penyebaran Pemakaian Platform Online}

Dalam masa pandemi Covid-19 ini, dosen dituntut untuk melaksanakan sistem pembelajaran daring. Berdasarkan data yang diperoleh dari penyebaran angket seperti terlihat pada gambar 4 kepada 64 responden untuk pemakaian platform online 82,8\% dosen berada di pulau Jawa. 7,8\% berasal dari pulau Sulawesi. Selebihnya tersebar di beberapa pulau yaitu Sumatera, Kalimantan, Papua dan Bali.

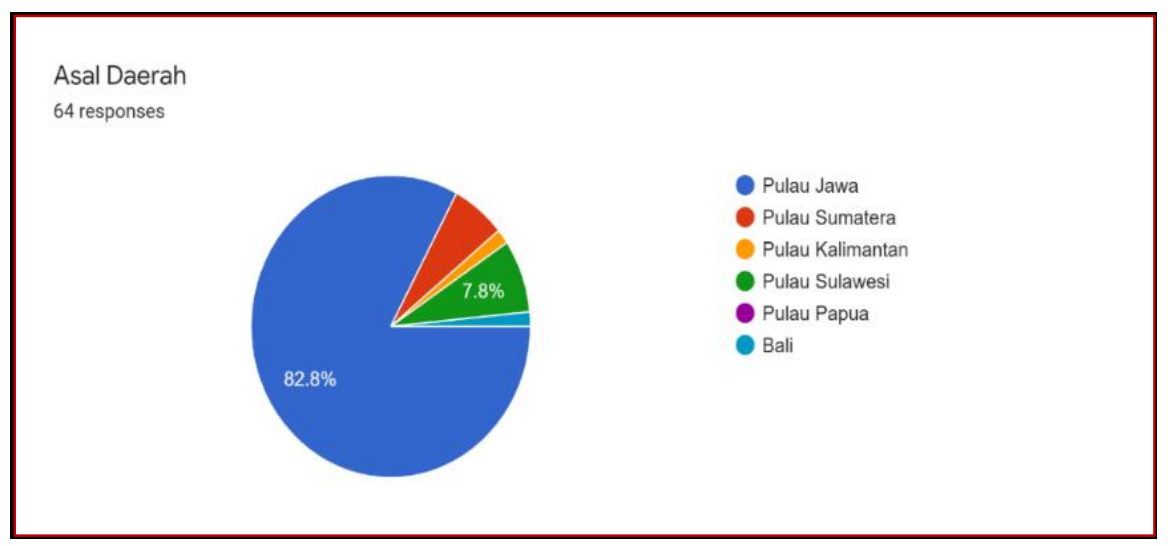

Gambar 4. Penyebaran platform online yang digunakan responden

Dengan 25\% dosen mengampu tiga matakuliah, 23,4\% dosen mengampu dua matakuliah, 20,3\% dosen mengampu empat mata kuliah. Sisanya 15,6\% dosen mengampu satu matakuliah, dan 10,9\% dosen mengampu diatas lima matakuliah dengan jumlah kelas 40,6\% responden dosen mengampu di atas lima kelas, 20,3\% mengampu tiga kelas, 18,8\% mengampu empat kelas dan bidang Keilmuan 43,8\% responden dosen melaksanakan pembelajaran daring di bidang ekonomi dan selanjutnya di bidang pendidikan sebanyak $20,3 \%$.

\section{Jenis Media Online yang Digunakan Dalam Perkuliahan}

Terlihat pada gambar 5, media online yang digunakan oleh responden dosen dalam pembelajaran daring dimasa pandemi Covid-19 ini mayoritas sebesar 56,3\% menggunakan Whatsapp, dan 40,6\% menggunakan platform Zoom, Google Classroom dan platform lainnya. 


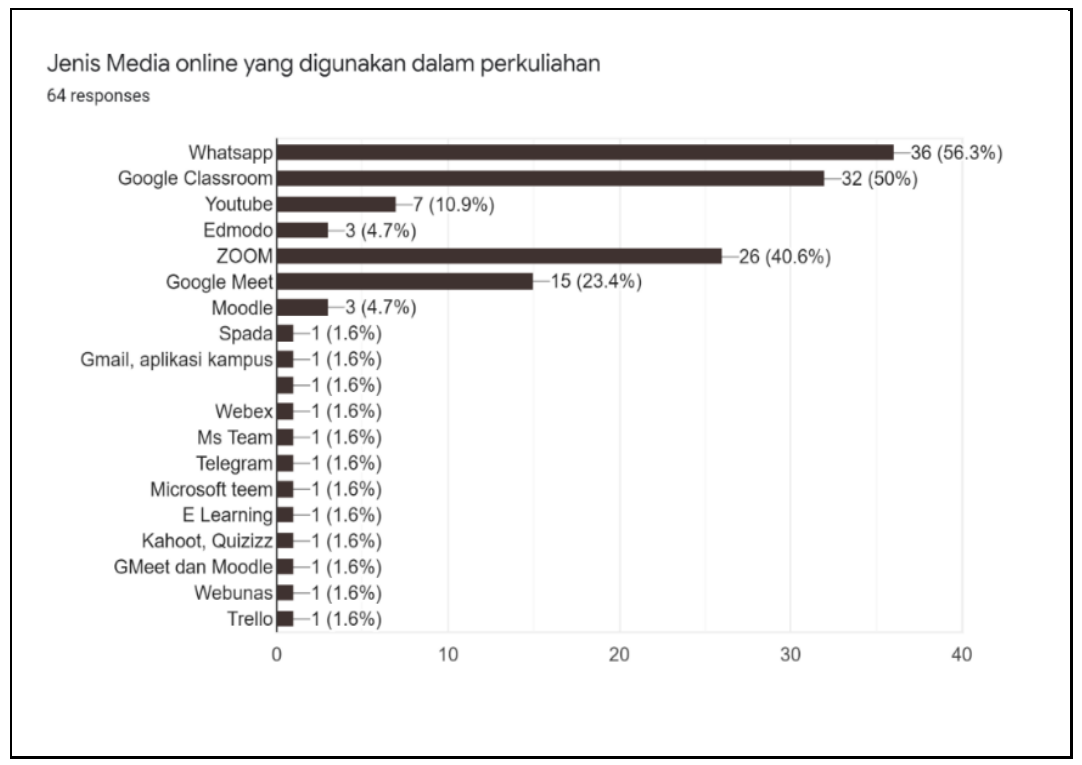

Gambar 5. Jenis platform online yang digunakan dalam perkuliahan online

Dari survei yang dilakukan mengenai perangkat pembelajaran yang digunakan terlihat pada gambar 6 berikut didapat sebanyak 67,2\% menggunakan handphone dan laptop, sedangkan 26,6\% hanya menggunakan laptop saja.

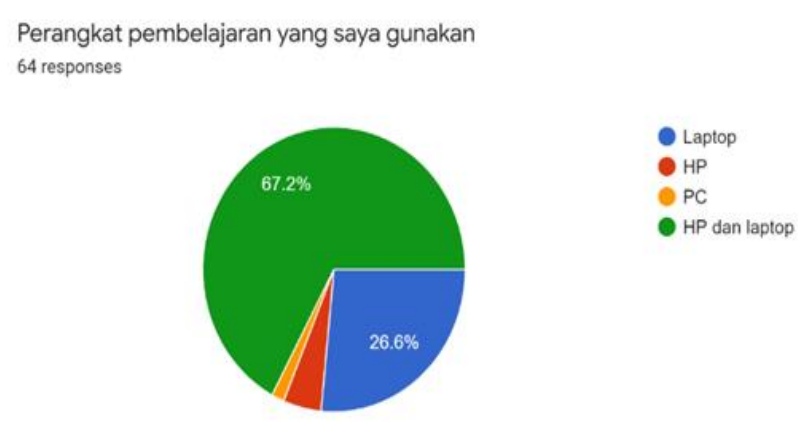

Gambar 6. Perangkat pembelajaran yang digunakan dalam perkuliahan online

\section{Pelaksanaan Pembelajaran Online}

Dalam pemanfaatan jam perkuliahan hasil angket menunjukkan sebanyak 65,6\% perkuliahan online dilaksanakan sesuai dengan jam perkuliahan, sebanyak $25 \%$ lebih lama dari jam perkuliahan, sedangkan hanya 7,8\% pemanfaatan jam perkuliahan lebih pendek dari jam perkuliahan. Sementara itu, teknis kehadiran mahasiswa sebanyak 43,8\% responden menggunakan teknis mahasiswa yang online dianggap hadir, sedangkan sebanyak 32,8\% responden menggunakan teknis diabsen satu satu. Sebanyak $15,6 \%$ responden menggunakan interaktif menulis.

Untuk kegiatan persiapan perkuliahan, sebanyak $43,8 \%$ responden melakukan persiapan materi perkuliahan, sebanyak 34,4\% responden mengikuti RPS, dan sebanyak 18,8\% mempersiapkan Power Point presentation. Dari hari survei kepada responden sebanyak 78,1\% telah sesuai dengan Rancangan Pembelajaran Semester (RPS) dan sebanyak 18,8\% kurang sesuai dengan Rancangan Pembelajaran Semester (RPS). Mayoritas atau sebanyak 82,8\% responden target materi dan tujuan matakuliah dalam RPS telah tercapai dengan perkuliahan online, sedangkan 17,2\% responden tidak tercapai target materi dan tujuan matakuliah dalam RPS. Hal ini berdasarkan jawaban responden terkait hambatan dalam pembelajaran online.

Jawaban responden terkait waktu pengumpulan tugas sebesar 39,1\% menjawab tergantung pada bobot kesulitan tugas. Sebanyak 26,6\% dikumpulkan pada pertemuan yang akan datang. Selebihnya dikumpulkan satu minggu kemudian dan hari itu juga. Sebanyak $60.9 \%$ jawaban responden menyatakan kadang-kadang memberikan tugas tergantung dari materi yang diberikan, sedangkan $39,1 \%$ responden memberikan tugas di setiap pertemuan. 


\section{Metode Pembelajaran dan Pemberian Tugas}

Hasil survey mengenai metode pembelajaran dan pemberian tugas terlihat pada gambar 7 sebanyak 52 responden ( $81,3 \%)$ memberikan tugas, dan sisanya mereka juga melakukan diskusi dalam metode pembelajarannya $(51,6 \%)$ dan $43,8 \%$ memberikan kuis. Selebihnya memberikan tutorial dan membuat ringkasan.

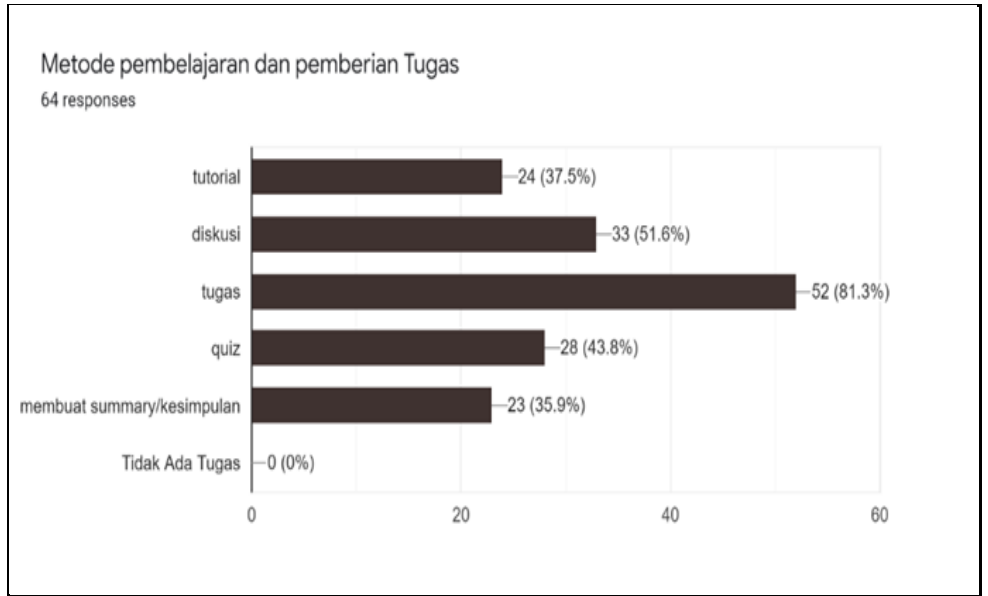

\section{Gambar 7. Metode Pembelajaran yang digunakan dalam perkuliahan online}

Pada gambar 8 mengenai pemberian tugas, dari jawaban responden jenis tugas yang diberikan sebanyak 46,99\% memberikan tugas dalam bentuk memberikan pertanyaan dan dijawab oleh mahasiswa. Sebanyak 37,5\% responden memberikan tugas studi kasus kepada mahasiswa. Dan sisanya memberikan tugas dalam bentuk membaca referensi yang diberikan dan praktek dari hasil materi yang diberikan.

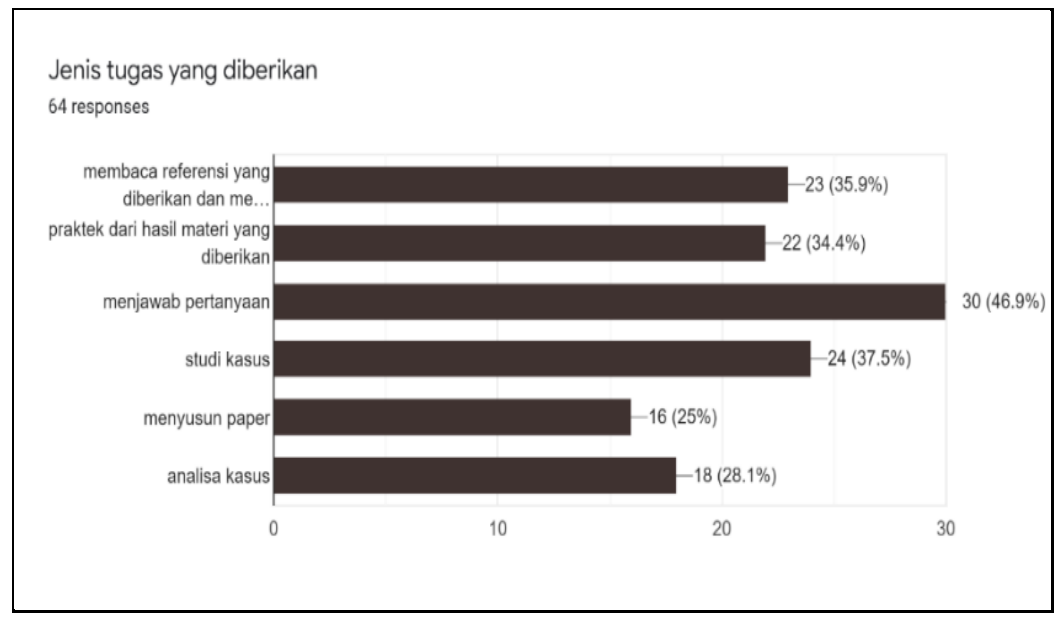

Gambar 8. Pemberian tugas dalam perkuliahan online

Jawaban responden terkait dampak dari pemberian tugas yang dapat memungkinkan menimbulkan stress mahasiswa didapat seperti dalam gambar 9 didapat sebesar 25\% dan 57,8\% tidak menimbulkan stress bagi mahasiswa. Sebesar 50\% responden menyatakan tingkat penerimaan mahasiswa terhadap perkuliahan daring Baik, sedangkan sebanyak 32,8\% menyatakan biasa saja. 


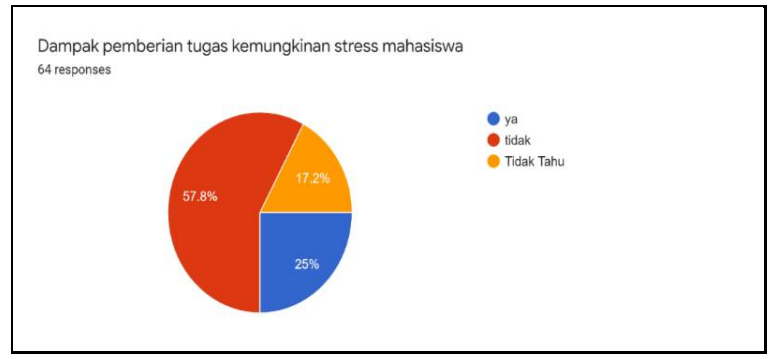

Gambar 9. Dampak pemberian tugas selama pembelajaran online

\section{Kelebihan dan Kekurangan Pemakaian Media Online dalam Perkuliahan Online}

Dari hasil survei seperti terlihat pada gambar 10, jawaban responden menyampaikan kelebihan pemakaian media online dalam perkuliahan mendukung penyampaian materi dengan menarik, hal ini dibuktikan sebanyak 51,6\% responden. Sebanyak $21,9 \%$ responden menjawab kelebihan pemakaian media online membuat kelas aktif, partisipasi mahasiswa ada dan komunikatif.

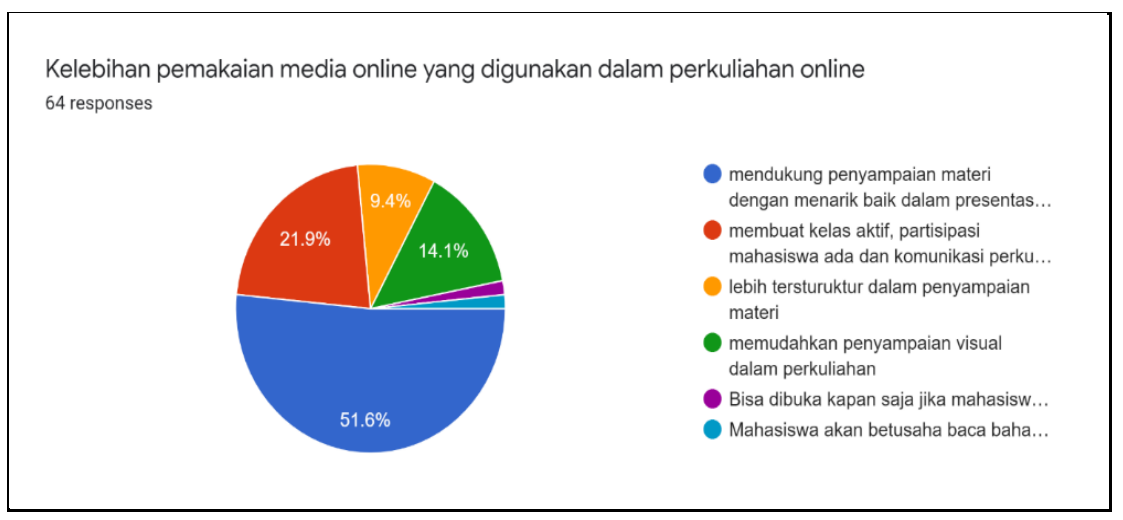

\section{Gambar 10. Kelebihan pemakaian platform online yang digunakan dalam perkuliahan online}

Selain terdapat kelebihan dalam pemakaian media online dalam perkuliahan online, terdapat kekurangan pemakaian media online yang disampaikan oleh responden pada gambar 11 bahwa sebanyak 28,1\% responden menjawab boros kuota, sedangkan sebanyak $25 \%$ menyatakan kurang interaktif dan komunikasi perkuliahan kurang lancar dan cenderung satu arah. Sebanyak $12,5 \%$ menyatakan kekurangan pembelajaran online tingkat partisipasi mahasiswa yang rendah.

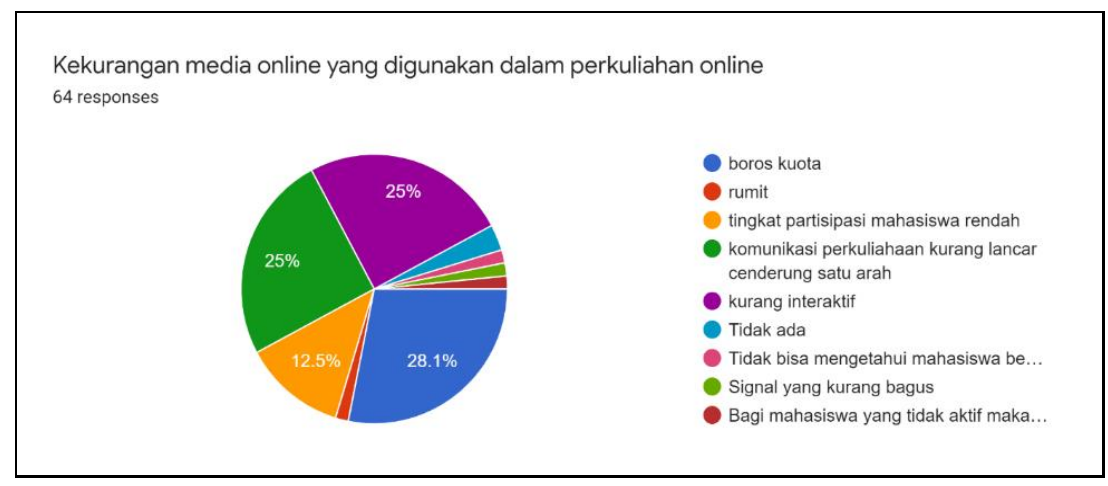

Gambar 11. Kekurangan pemakaian platform online dalam perkuliahan online

\section{Hambatan Perkuliahan Online}

Terlihat pada gambar 12, dari jawaban responden terdapat 40,6\% menyatakan hambatan dari perkuliahan online dikarenakan tidak ada quota dan sinyal. Sebanyak 23,4\% responden menyatakan kurangnya keseriusan dalam perkuliahan online. Sebanyak 15,6\% terdapat hambatan berupa kurang interaktif dan GAPTEK pada media online yang digunakan. 


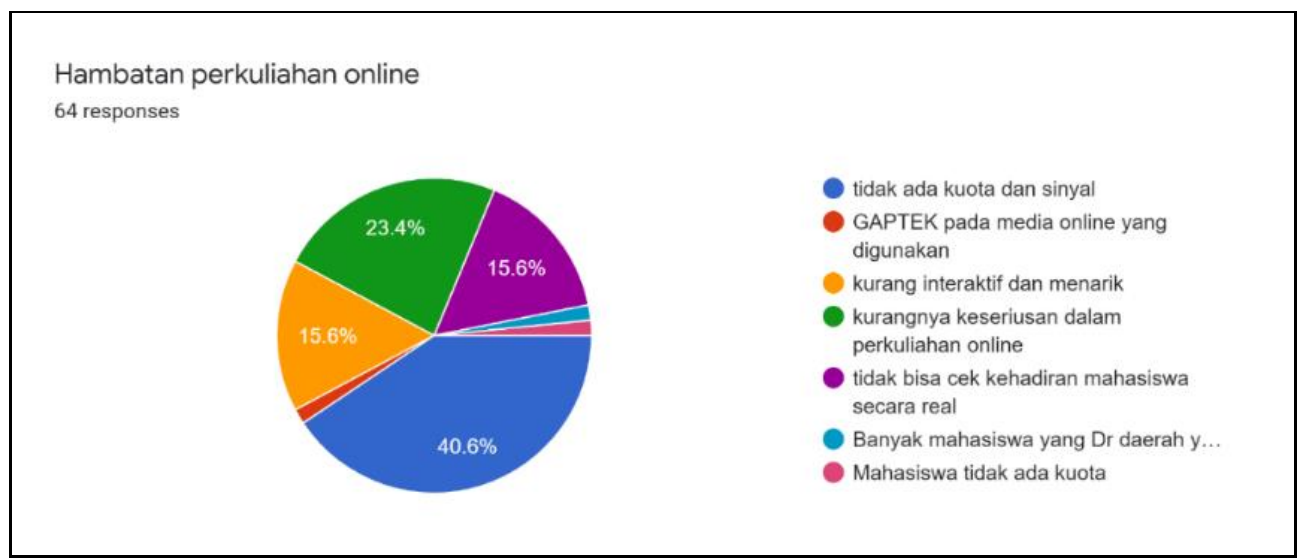

Gambar 12. Kendala pemakaian platform online dalam perkuliahan online

\section{Upaya Mengatasi Kendala dalam Perkuliahan Online}

Upaya mengatasi masalah dalam perkuliahan online terlihat pada gambar 13 bahwa 50\% responden menggunakan media yang efektif dan efisien, tidak boros kuota dan mudah diakses, sedangkan sebanyak 23,4\% responden melakukan upaya perkuliahan online dengan media online yang digunakan dengan cara membuat materi ajar yang menarik dan dapat diakses mahasiswa kapan saja.

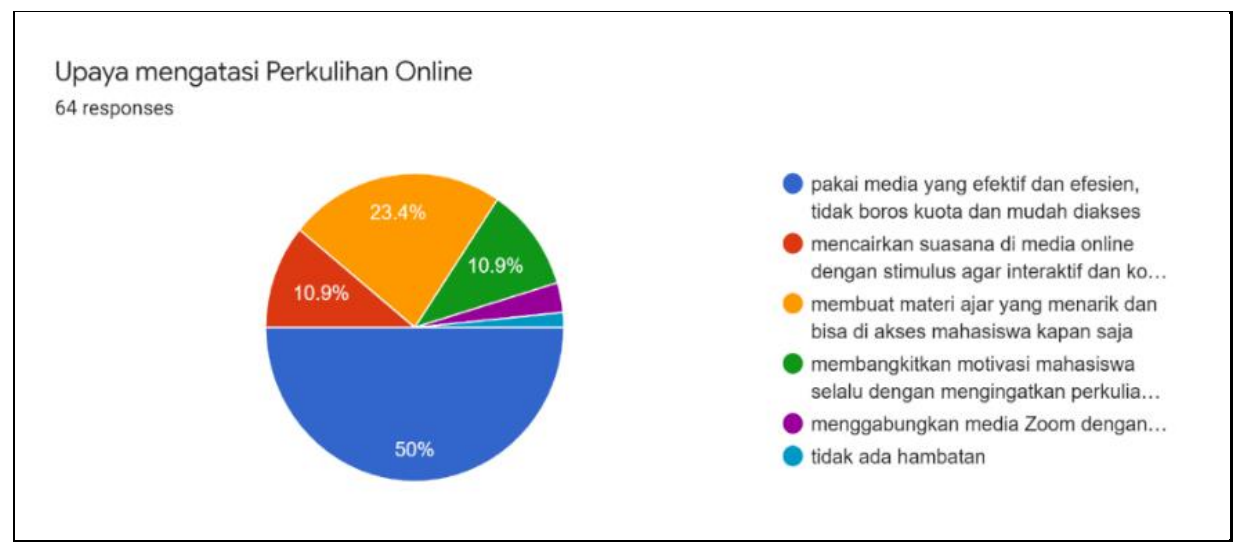

\section{Gambar 13. Upaya mengatasi kendala pemakaian platform online dalam perkuliahan online}

\section{PEMBAHASAN}

Dengan keadaan yang mendadak dan terbatasnya sarana teknologi informasi dan komunikasi dalam perkuliahan online di masa pandemi ini dosen tetap berusaha memanfaatkan platform online yang ada untuk memberikan perkuliahan online. Menurut Milman (2015) penggunaan teknologi digital dapat memungkinkan mahasiswa dan dosen melaksanakan proses pembelajaran walaupun mereka di tempat yang berbeda. Pemanfaatan teknologi pembelajaran merupakan tantangan bagi dosen dan mahasiswa dan terus ditingkatkan kualitasnya. (Junedi, Mahuda, \& Kusuma 2020). Pemanfaatan ini didukung teknologi yang perlu ditingkatkan kualitasnya, seperti fasilitas-fasilitas yang digunakan perusahaan provider penyedia platform online.

\section{Jenis Platform Online}

Hasil penelitian menunjukkan bahwa mayoritas platform online yang digunakan oleh responden dosen dalam perkuliahan online dimasa pandemi covid 19 ini Whatsapp dengan sebesar 56,3\% sedangkan yang lainnya sebesar 44\% menggunakan platform lain seperti Google Classroom Zoom dan berbagai macam jenisnya. Fitur whatsApp sederhana dan mudah digunakan, Platform berbasis chatting ini paling banyak digunakan dan tidak perlu dipelajari lagi seperti yang lainnya. Sebagian besar dosen menggunakan WhatsApp untuk berkomunikasi dengan grup mata kuliah tertentu. Memberikan informasi terkait dengan perkuliahan, penugasan dan ujian akhir. Melalui WhatsApp pengajar dapat mengirimkan link meeting untuk kuliah tatap muka, penugasan maupun ujin (Bafadal \& Triansyah 2020). Selain itu WhatsApp mayoritas dipunyai dikarenakan saat ini whatsapp merupakan media pengirim pesan paling besar saat ini dengan persentase pengguna sebesar 95,3 juta pengguna di Indonesia sehingga menjadikan whatsapp sebagai aplikasi online paling populer. Sementara itu pada era digital saat ini, aplikasi WhatsApp 
sudah sering dipergunakan dalam aktivitas keseharian Sehingga para mahasiswa tidak banyak mengalami kesulitan dalam mengikuti perkuliahan yang diberikan oleh dosen melalui aplikasi WhatsApp ini dibanding menggunakan aplikasi lainnya. Penelitian lain juga menyatakan bahwa penggunaan WhatsApp yang efektif di kelas memiliki dampak positif untuk menggabungkannya dengan metode atau strategi lain dalam mencapai tujuan pembelajaran (Damanik, 2019).

Aplikasi platform online dipilih dosen karena dapat digunakan sesuai kebutuhan penggunanya. WhatsApp dapat mengirim pesan teks, pesan suara dan video, berbagai macam gambar/foto, video, dokumen materi pembelajaran dan lainnya. Aplikasi Google Classroom fungsinya sama seperti WhatsApp, tetapi aplikasi tersebut biasa digunakan untuk diskusi dan mengirim tugas agar lebih mudah dan rapi, sedangkan aplikasi Google Meet dan Zoom untuk pertemuan tatap muka secara daring agar dosen dapat melihat wajah mahasiswa yang memperhatikan dosen saat memberikan penjelasan materi. Pemakaian paltform online sendiri juga membutuhkan kesiapan dosen, mereka dituntut mempunyai kemampuan dan ketrampilan dalam menggunakan media penunjang perkuliahan online, menyediakan sumber materi yang variatif dan kreatif serta intens berkomunikasi melalui platform ynag digunakan dengan mahasiswa. Dengan melalui proses seperti ini maka pembelajaran diharapkan berkembang dan berkualitas perlu dikembangkan kapasitas kelembagaan literasi digital dosen dan mahasiswa (Kusuma, dkk, 2020).

\section{Pemanfaatan Platform Online}

Dalam pemanfaatan platform online dimasa pandemi, hasil penelitian juga menunjukkan bahwa platform online dipergunakan untuk pembelajaran online dimasa pandemi $65,6 \%$ sudah sesuai jam perkuliahan terlihat sebanyak $65,6 \%$ sesuai dengan jam perkuliahan, dengan sebanyak $25 \%$ lebih lama dari jam perkuliahan, sedangkan hanya 7,8\% dalam pemanfaatan jam perkuliahan lebih pendek dari jam perkuliahan. Hal ini menunjukkan meskipun platform online tidak terbatas ruang dan waktu, tetapi masih bisa menerapkan displin waktu pelaksanaan perkuliahann. Mengingat kesuksesan pembelajaran daring selama masa krisis Covid-19 ini tergantung pada kedisiplinan semua pihak, oleh karena itu diperlukan manajemen yang baik dalam mengatur sistem pembelajaran daring. dengan membuat jadwal yang sistematis, terstruktur dan simpel untuk agar optimalisasi proses pembelajaran daring bisa berjalan dengan baik, maka kedisiplinan tingkat tinggi mutlak dibutuhkan baik Baik dari sisi SDM dosen maupun para mahasiswa. Mahasiswa yang cerdas dan memiliki disiplin serta kepercayaan diri yang tinggi akan mampu secara efektif melakukan pembelajaran secara daring. hubungan yang erat antara perkuliahan online dengan sikap mental dari para mahasiswa peserta perkuliahan (Watnaya, dkk, 2020).

Teknis penghitungan kehadiran mahasiswa terihat lebih variatif seperti sebanyak 43,8\% responden menggunakan teknis mahasiswa yang online dianggap hadir, sedangkan sebanyak 32,8\% responden menggunakan teknis diabsen satu satu. Sebanyak $15,6 \%$ responden menggunakan interaktif menulis. Kegiatan ini juga sebagai bentuk komunikasi antara dosen, dan mahasiswa yang terjalin guna keberhasilan pembelajaran online. Pembelajaran online membutuhkan kesiapan dalam pelaksanaan dari hasil penelitian kegiatan persiapan perkuliahan, sebanyak 43,8\% responden melakukan persiapan materi perkuliahan, sebanyak 34,4\% responden mengikuti RPS, dan sebanyak 18,8\% mempersiapkan Power Point presentation. Dari hari survei kepada responden sebanyak 78,1\% telah sesuai dengan Rancangan Pembelajaran Semester (RPS) dan sebanyak 18,8\% kurang sesuai. Hasil survey mengenai metode pembelajaran dan pemberian tugas sebanyak 52 responden $(81,3 \%)$ memberikan tugas, sebanyak 33 responden $(51,6 \%)$ melakukan diskusi dalam metode pembelajarannya, dan sebanyak 28 responden atau 43,8\% memberikan kuis, selebihnya memberikan tutorial dan membuat summary. Sebanyak $60.9 \%$ jawaban responden menyatakan kadang-kadang memberikan tugas tergantung dari materi yang diberikan, sedangkan 39,1\% responden memberikan tugas di setiap pertemuan. Demikian juga, diperlukan penyesuaian terhadap kurikulum yang diajarkan atau metode belajar mengajar. Mengembangkan strategi yang diperlukan untuk mengajar dan belajar online dengan sukses membutuhkan pemahaman tentang gaya belajar dan bagaimana mereka dapat ditangani dengan baik di lingkungan online (Lewis, Whiteside, Dikkers, 2015).

Jawaban responden terkait waktu pengumpulan tugas sebesar 39,1\% menjawab tergantung pada bobot kesulitan tugas. Sebanyak 26,6\% dikumpulkan pada pertemuan yang akan datang. Selebihnya dikumpulkan satu minggu kemudian dan hari itu juga. Sebanyak $60.9 \%$ jawaban responden menyatakan kadang-kadang memberikan tugas tergantung dari materi yang diberikan. Sedangkan 39,1\% responden memberikan tugas di setiap pertemuan. Dari jawaban responden jenis tugas yang diberikan sebanyak 30 orang atau $46,99 \%$ memberikan tugas dalam bentuk memberikan pertanyaan dan dijawab oleh mahasiswa. Sebanyak $37,5 \%$ responden memberikan tugas studi kasus kepada mahasiswa. Sebesar 22 dan 23 responden memberikan tugas dalam bentuk membaca referensi yang diberikan dan praktik dari hasil materi yang diberikan. Mayoritas atau sebanyak $82,8 \%$ responden target materi dan tujuan mata kuliah dalam RPS telah tercapai dengan perkuliahan online, sedangkan $17,2 \%$ responden tidak tercapai target materi dan tujuan matakuliah dalam RPS. Hal ini berdasarkan jawaban responden terkait hambatan dalam pembelajaran online. Selain itu, untuk setiap tugas yang diberikan kita memberlakukan sistem deadline, atau batas waktu pengumpulan, dan memastikan seluruh mahasiswa dapat mengikuti dan mengerjakan tugas ynag diberikan.

Dalam pelaksanaan pembelajaran daring sebaiknya tugas dan aktivitas lebih ditekankan pada peningkatan ketrampilan dan pengalaman dengan memepertimbangkan juga kesenjangan akses internet dan fasilitas yang dimiliki mahasiswa. Mahasiswa harus mempersiapkan dirinya, mengevaluasi, mengatur dan secara terus menerus selalu termotivasi dalam mengikuti pembelajaran karena pembelajaran daring berkonsep belajar mandiri (self learning). Dari survei juga diketahui bahwa dalam mengikuti perkuliahan online perangkat pembelajaran yang digunakan sebanyak $67,2 \%$ menggunakan handphone dan laptop, sedangkan 26,6\% hanya menggunakan laptop saja. Sarana dan prasarana merupakan syarat pendukung yang mutlak dalam pembelajaran berbasis e-learning yang berkualitas (Rustiani, dkk, 2019). 


\section{Kelebihan dan Kekurangan Pemanfaatan Platform Online}

Kelebihan pemakaian media online dalam perkuliahan, yaitu mendukung penyampaian materi dengan menarik. Hal ini dibuktikan sebanyak 51,6\% responden. Interaksi yang lancar juga menunjukkan tingkat respons yang tinggi Sebanyak 21,9\% responden menjawab kelebihan pemakaian media online membuat kelas aktif, partisipasi mahasiswa ada dan komunikatif. interaksi terjadi dalam WhatsApp biasanya interaksi mahasiswa dan dosen akan lebih mudah. Dalam penggunaannya pun mahasiswa sudah sangat paham dan hampir semua mahasiswa mempunyai WhatsApp. Dalam perkuliahan online dengan whatsapp dosen memberikan materi dalam bentuk file bisa jenis powerpoint dan ms, word, kemudian dijelaskan dengan pesan suara. Untuk tugas kuliah dosen lebih menerapkan pada kemandirian mahasiswa dengan pemberian tugas seperti menulis artikel atau jurnal, membuat video, presentasi indicidu atau kelompok dan lainnya yang sifatnya kreatif, inovatif dan partisipatif dengan tujuan memberikan pengalaman dan pengetahuan baru. Menurut Purwanto, dkk (2020) keuntungan pembelajaran online adalah waktu tidak terbatas, masih banyak waktu luang, menghemat biaya transportasi.

Banyak kendala yang dihadapi dalam pemanfatan platform online, kekurangan pemakaian media online yang disampaikan oleh responden bahwa sebanyak $28,1 \%$ responden menjawab boros kuota, hal yang menarik selain sebanyak $25 \%$ responden menyatakan media pembelajaran kurang interaktif dan komunikasi perkuliahan kurang lancar dan cenderung satu arah akses internet yang kurang memadai, boros kuota dan mahasiswa mengalami kesulitan dalam memahami materi. Kekurangan lain yaitu kurangnya dosen interaksi dengan mahasiswa bila dibandingkan dengan perkuliahan tatap muka, dosen tidak tahu karakteristik mahasiswanya (Nuriansyah 2020). Hal ini juga muncul pada hasil penelitian lainya seperti (Irfan et al. 2020) ketersediaan fitur pada portal akademik masing-masing perguruan tinggi, masih terbatasnya interaksi antara dosen dan mahasiswa. Tantangan lain dari pembelajaran daring ketidakstabilan jaringan internet serta mahalnya biaya kuota (Sadikin \& Hamidah 2020). Pemahaman materi yang kurang maksimal, dan melawan rasa malas yang semakin meningkat. Sebanyak 12,5\% menyatakan kekurangan pembelajaran online tingkat partisipasi mahasiswa yang rendah.

Respons terhadap dampak dari pemberian tugas yang dapat memungkinkan menimbulkan stress mahasiswa sebesar $25 \%$ dan 57,8\% tidak menimbulkan stress bagi mahasiswa. Sebesar 50\% responden menyatakan tingkat penerimaan mahasiswa terhadap perkuliahan daring Baik, sedangkan sebanyak 32,8\% menyatakan biasa saja. Sebanyak 23,4\% responden melakukan upaya perkuliahan online dengan media online yang digunakan dengan cara membuat materi ajar yang menarik dan dapat diakses mahasiswa kapan saja. Dalam pembelajaran online memungkinkan dosen untuk memberikan perkuliah yang dapat diikuti kapanpun dan dimanapun tidak terikat ruang dan waktu. Dengan demikian, mahasiswa mempunyai kebabasan untuk memilih mata kuliah dan tugas yang harus diikuti serta dikerjakan lebih dulu. Hal ini sejalan dnegan hasil penelitian Sun, et al (2008) bahwa kepuasaan mahasiswa dalam pembelajaran daring dipengaruhu flesibilitas waktu, metode pembelajaran dan tempat pembelajaran.

Keuntungan penting lainnya data yang dapat direkam dapat digunakan kembali, pengurangan biaya transportasi. Menurut Purwanto, dkk (2020) keuntungan pembelajaran online adalah waktu tidak terbatas, masih banyak waktu luang, menghemat biaya transportasi sedangkan kerugiannya adalah penyampaian materi tidak jelas, adanya kejenuhan dan suasana yang monoton kurangnya interaksi siswa dengan guru. Menurut Putri, dkk (2020) keuntungan pembelajaran online adalah waktu tidak terbatas, masih banyak waktu luang, menghemat biaya transportasi sedangkan kerugiannya adalah penyampaian materi tidak jelas, kurangnya interaksi siswa dengan guru. keuntungan pembelajaran online adalah waktu tidak terbatas, masih banyak waktu luang, menghemat biaya transportasi (Setyorini, 2020).

\section{Kendala dan Upaya Mengatasinya}

Pembelajaran online dengan berbagai platform di masa pandemi Covid-19 saat ini tentu tidak terlepas dengan berbagai permasalah dalam pelaksanaanya. Belum adanya infrastruktur TIK serta belum merata ketersediaan infrastruktur digital sebagai syarat mutlak pembelajaran jarak jauh yang memadai dan meluas menyebabkan belum optimalnya pelaksanaan proses pembelajaran online. Kesiapan Pembelajaran Jarak Jauh membuat kepanikan baik dosen dan mahasiswa. Hal ini karena terdapatnya keadaan sosio-ekonomi yang memengaruhi tingkat komptensi dan literasi digital dan TIK, tidak dapat dipungkiri dalam menjalani perkuliahan daring menyebabkan dosen dan mahasiswa yang tidak melek teknologi akan bermasalah dalam mengelola pembelajaran atau mengikuti proses pembelajaran. Fitriani \& Atmojo (2020) menyatakan bahwa masalah multidimensi dalam pembelajaran jarak jauh berhubungan dengan keadaan status sosial, ketersediaan kuota internet serta kemampuan dalam mengoperasikan digital, semua masalah tersebut akan memengaruhi kualitas pembelajaran jarak jauh.

Pemasalahan lain yaitu permasalahan teknis seperti ketersedian kouta, ketidakstabilan sinyal, sampai permasalahan literasi platform online yang digunakan. Hal ini terlihat dari respons sebesar 40,6\% menyatakan hambatan dari perkuliahan online dikarenakan tidak ada quota dan sinyal. Sebanyak 23,4\% responden menyatakan kurangnya keseriusan dalam perkuliahan online. Sebanyak 15,6\% terdapat hambatan berupa kurang interaktif dan gaptek pada media online yang digunakan. Adapun 50\% responden menggunakan media yang efektif dan efisien, tidak boros kuota dan mudah diakses. Hal ini menyebabkan pembelajaran online tidak efektif karena seyogyanya efektivitas selain diukur dari tingkat prestasi belajar juga dari proses dan fasilitas penunjang. Menurut Mukarromah \& Utomo (2020) tingkat keberhasilan dari suatu proses pembelajaran ditentukan dari keefektifan metode pembelajaran yang digunakan. 
Gangguan dalam pembelajaran online juga muncul karena ada faktor eksternal dan internal. Kendala waktu, lemahnya dukungan dari lingkungan, dan masalah biaya merupakan sebagaian dari faktor eksternal yang muncul. Terdapat kekurangan pemakaian media online yang disampaikan oleh responden bahwa sebanyak 28,1\% responden menjawab boros kuota, sedangkan sebanyak 25\% menyatakan kurang interaktif dan komunikasi perkuliahan kurang lancar dan cenderung satu arah. akses internet yang tidak stabil, kurang otimalnya dalam memahami materi, dan pasifnya mahasiswa yang semakin meningkat. Sebanyak $12,5 \%$ menyatakan kekurangan pembelajaran online tingkat partisipasi mahasiswa yang rendah. Hal ini berkaitan dengan mentalitas mahasiswa dalam proses pembelajaran yang menemui kendala dan deadline tugas secara terus menerus diberikan. Menurut Seran, Utomo, \& Handoyo (2020) ganguan dalam pembelajaran online mungkin dapat memengaruhi aspek psikologis mahasiswa. Ditambah pemasalahan ekonomi seperti tuntutan kebutuhan sehari-hari, ditambah dengan kebutuhan internet sehingga menambah beban keuangan mahasiswa. Sementara faktor internal berkaitan dengan kedisiplinan serta kemampuan dalam mengatur waktu mengikuti kegiatan pembelajaran, termasuk kemampuan mahasiswa fokus dalam perkuliahan. Faktor lainya ialah aplikasi online yang belum ramah kepada penguna, literasi digital teknologi yang kurang, rendahnya interaksi dalam proses perkuliahan, ditambah harus belajar mandiri dengan tanpa pendampingan dalam pembelajaran secara langsun. Faktor-faktor tersebut sangat memengaruhi keputusan mahasiswa untuk tetap mengikuti perkuliahan daring, yang tentu saja hal ini akan memengaruhi penilaian pembelajaran (Rodriquez, Dwiyogo, \& Supriyadi 2020).

\section{SIMPULAN}

Keadaan pandemi Covid-19 telah memaksa proses pelaksanaan pembelajaran menggunakan platform online. Pemanfaatan platform online oleh dosen dan mahasiswa membutuhkan kesiapan baik kemampuan, keterampilan dalam penggunaan aplikasi. Hasil penelitian persentase besar menunjukkan dosen lebih cenderung menggunakan paltform yang sudah familiar dikenal dan mudah digunakan seperti WhatsApp dengan tetap melakukan teknis seperti dalam pembelajaran tatap mukas seperti jadwal pelaksanan perkuliahan sesuaai jadwal, adanya absensi kehadiran, materi tetap mengacu ke RPS, evaluasi materi dengan penugasan yang variatif dan tetap mengupayakan solusi terhadap masalah atau kendala yang ada.

Pemanfaatan platform online dalam pembelajaran online mempunyai kelebihan dan kekurangan. Bergesernya metode tatap muka menjadi online membutuhkan adaptasi, dari proses dari persiapan materi, pelaksaanaan pembelajaran, evaluasi serta interaksi dalam ruang digital. Adaptasi ini dipelukan agar tidak muncul kesenjangan sosial diantara mahasiswa (Gusdiyanto, Dwiyogo, \& Adi, 2020). Dengan demikian, dibutuhkan dukungan perguruan tinggi dalam menyediakan sarana dan juga meningkatkan solidaritas antar masyarakat dimasa pandemi ini. Pendidikan tinggi pada pandemi Covid-19 saat ini menjalankan misi kalksiknya yang hakiki yaitu kepedulian dan solidaritas sosial yang universal (Hamidah \& Kusuma 2020).

Dapat disimpulkan secara keseluruhan kita belum mampu dan siap melakukan perkuliahan daring saat pandemi sekarang ini. Permasalahan seperti keterbatasan infrastruktur dan fasilitas TIK, literasi digital dosen dan mahasiswa dalam menggunakan platform online, permasalahan signal, kemampuan ekonomi, belum opimalnya dalam memahami materi yang diberikan dalam pembelajaran jarak jauh.

\section{DAFTAR RUJUKAN}

Enriquez, M. A. S. (2014). Students Perceptions on the Effectiveness of the Use of Edmodo as a Supplementary Tool for Learning. DLSU Research Congress 6-11. doi: 10.1017/CBO9781107415324.004.

FirmaN., \& Rahman, S. R. (2020). Pembelajaran Online di Tengah Pandemi Covid-19. Indonesian Journal of Educational Science (IJES), 2(2), 81-89.

Fitriani, W., Haryanto., \& Atmojo, S. E. (2020). Motivasi Berprestasi dan Kemandirian Belajar Mahasiswa Saat Pembelajaran Daring. Jurnal Pendidikan: Teori, Penelitian, dan Pengembangan, 5(6), 828-834.

Gusdiyanto, H., Dwiyogo, W. D., \& Adi, S. (2020). Pembelajaran Blended Learning Sosio Antropologi Olahraga untuk Mahasiswa Pendidikan Jasmani dan Kesehatan. Jurnal Pendidikan: Teori, Penelitian, dan Pengembagan, 5(1), 7-14.

Hamidah., \& Kusuma, J. W. (2020). Analysis of Student Learning Styles and Geometry Thinking Skills: During the Covid-19 Pandemic. Journal of Physics: Conference Series 1657:012036. doi: 10.1088/1742-6596/1657/1/012036.

Herliandry, L. D., Nurhasanah., Suban M. E., \& Heru, K. (2020). Transformasi Media Pembelajaran Pada Masa Pandemi Covid-19. Jurnal Teknologi Pendidikan, 22(1), 65-70.

Hidasari, F.P., Bafadal, M. F., \& Triansyah, A. (2020). Pemanfaatan Platform Digital untuk Studi Online dalam Pendidikan Jasmani. SCIENCE TECH: Jurnal Ilmu Pengetahuan dan Teknologi, 6286(2), 48-57.

Irfan, M., Kusumaningrum, B., Yulia, Y., \& Widodo, S. A. (2020). Challenges During the Pandemic: Use of E-Learning in Mathematics Learning in Higher Education. Infinity Journal, 9(2), 147. doi: 10.22460/infinity.v9i2.p147-158.

J. L. Moore, C. Dickson-Deane., \& K. Galyen. (2011). E-Learning, Online Learning, and Distance Learning Environments: Are They the Same? The Internet and Higher Education, 14(2), 129-35.

Junedi, B., Isnaini, M., \& Kusuma, J. W. (2020). Optimalisasi Keterampilan Pembelajaran Abad 21 Dalam Proses Pembelajaran Pada Guru MTs Massaratul Mut'allimin Banten. Transformasi: Jurnal Pengabdian Masyarakat, 16(1), 63-72. doi: 10.20414/transformasi.v16i1.1963. 
Kusuma, J. W., Jefri, U., Hidayat, A., \& Hamidah. (2020). Application of Treffinger Learning Model to Improve Creative Reasoning and Mathematical Problem Solving Skills as Well as Student Learning Interests. JTAM (Jurnal Teori dan Aplikasi Matematika), 4(2), 204. doi: 10.31764/jtam.v4i2.2840.

Lewis, S., Whiteside, A., \& Dikkers, A. (2015). Providing Chances for Students to Recover Credit: Is Online Learning a Solution? Exploring Pedagogies for Diverse Learners Online (Advances in Research on Teaching, 25, $143-157$.

Milman, N. B. (2015). Distance Education. In International Encyclopedia of the Social \& Behavioral Sciences: Second Edition $567-70$.

Mukarromah, M., Budijanto., \& Utomo, D. H. (2020). Pengaruh Model Challenge Based Learning terhadap Kemampuan Berpikir Kritis Siswa SMA pada Materi Perubahan Iklim. Jurnal Pendidikan: Teori, Penelitian, dan Pengembangan 5(2), 214-218.

Mukharomah, K., \& Qomariyah, N. (2020). Penggunaan Analitik Hirarki Proses Dalam Menentukan Preferensi Platform Pembelajaran Daring Selama Masa Tanggap Darurat Covid-19 Pada Mahasiswa UGM Yogyakarta. Universitias Gadjah Mada, Yogyakarta (April):1-10. doi: 10.13140/RG.2.2.11562.98248.

Nuriansyah, F. (2020). Efektivitas Penggunaan Media Online Dalam Meningkatkan Hasil Belajar Pada Mahasiswa Pendidikan Ekonomi Saat Awal Pandemi Covid-19. Jurnal Pendididikan Ekonomi Indonesia, 1(2), 61-65.

Pujilestari, Y. (2020). Dampak Positif Pembelajaran Online Dalam Sistem Pendidikan Indonesia Pasca Pandemi Covid-19. Adalah: Buletin Hukum \& Keadilan, 4(1), 49-56.

Purwanto, A., Pramono, R., Asbari, M., Santoso, P. B., Wijayanti, L. M., Choi, C. H., \& Putri, R. S. (2020). Studi Eksploratif Dampak Pandemi COVID-19 Terhadap Proses Pembelajaran Online di Sekolah Dasar. EduPsyCouns: Journal of Education, Psychology and Counseling, 2(1), 1-12.

Putri, R. S., Purwanto, A., Pramono, R., Asbari, M., Wijayanti, L. M., \& Choi Chi Hyun. 2020. Impact of the COVID-19 Pandemic on Online Home Learning: An Explorative Study of Primary Schools in Indonesia. International Journal of Advanced Science and Technology, 29(5), 4809-4818.

Rodriquez, E. I. S., Dwiyogo, W. D., \& Supriyadi. (2020). Blended Learning Matakuliah Sepakbola untuk Mahasiswa Pendidikan Jasmani Kesehatan dan Rekreasi. Jurnal Pendidikan: Teori, Penelitian, dan Pengembangan 5(2), $206-213$.

Rustiani., Djafar, S., Rusnim., Nadar., Arwan., \& Elihami. (2019). Measuring Usable Knowledge: Teacher's Analyses of Mathematics for Teaching Quality and Student Learning. International Conference on Natural and Social Sciences (ICONSS) Proceeding Series (September), 239-245.

Sadikin, A., \& Hamidah, A. (2020). Pembelajaran Daring di Tengah Wabah Covid-19. Biodik 6(2), 109-119. doi: 10.22437/bio.v6i2.9759.

Seran, W. A, Utomo, D. H. \& Handoyo, B. (2020). Pengaruh Model Pembelajaran Outdoor Study Berbantuan Video Conference terhadap Kemampuan Menulis Karya Ilmiah Mahasiswa. Jurnal Pendidikan: Teori, Penelitian, dan Pengembangan, 5(2), 142-152.

Sun, Pei Chen., Ray J. Tsai., Glenn Finger., Yueh Yang Chen., \& Dowming Yeh. (2008). What Drives a Successful ELearning? An Empirical Investigation of the Critical Factors Influencing Learner Satisfaction. Computers and Education 50(4):1183-1202. doi: 10.1016/j.compedu.2006.11.007.

Surani, D., \& Chaerudin, AR. (2019a). Pemanfaatan Media Whatsapp Grouping Dalam Peningkatan Kemampuan Bahasa Inggris Ekonomi Mahasiswa Fakultas Ekonomi dan Bisnis. Tarbawi: Jurnal Keilmuan Manajemen Pendidikan, 5(02), 155. doi: 10.32678/tarbawi.v5i02.2050.

Surani, D., \& Chaerudin, AR. (2019b). Studi Literatur: Peran Teknologi Pendidikan Dalam Pendidikan 4.0. Tarbawi: Jurnal Keilmuan Manajemen Pendidikan 5(02):155. doi: 10.32678/tarbawi.v5i02.2050.

Susilawati, S., \& Supriyatno, T. (2020). Online Learning Through WhatsApp Group in Improving Learning Motivation in the Era and Post Pandemic COVID -19.” Jurnal Pendidikan: Teori, Penelitian, dan Pengembangan, 5(6), 852-859.

Watnaya, A. K., Muiz, M. H., Sumarni, N., Mansyur, A. S., \& Zaqiah, Q. Y. (2020). Pengaruh Teknologi Pembelajaran Kuliah Online di Era Covid-19 dan Dampaknya terhadap Mental Mahasiswa. EduTeach : Jurnal Edukasi dan Teknologi Pembelajaran, 1(2):153-165. doi: 10.37859/eduteach.v1i2.1987. 